\title{
THE ROLE OF PARENTING STYLES ON VIOLENCE AMONG STUDENTS IN SECONDARY SCHOOLS IN EMBU COUNTY, KENYA
}

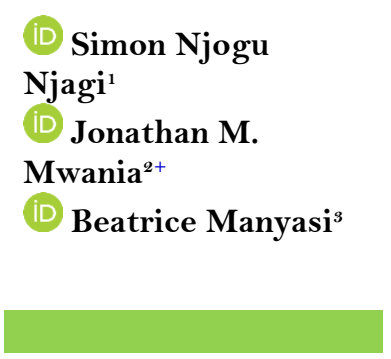

Article History

Received: 1 February 2018 Revised: 19 February 2018 Accepted: 23 February 2018 Published: 28 February 2018

\section{Keywords \\ Parenting styles Authoritative Authoritarian Permissive indulgence Permissive neglectful Violence.}

\author{
${ }^{1,3}$ School of Education Maasai Mara University, Kenya \\ ${ }^{2}$ Department of Educational psychology South Eastern Kenya University, \\ Kenya \\ ${ }^{2}$ Email:muemamwania@yahoo.com
}

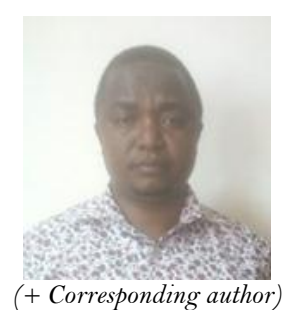

ABSTRACT

+ Corresponding author

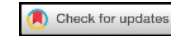

Youth violence, both in and out of school, is worldwide problem. Students' violence is manifested in form of bullying among students, physical fights gender violence and violence against school property during school strikes. Violence in secondary schools wastes a lot of learning time as students and teachers spend a lot of time dealing with disciplinary issues related to violence, at times it has also led to loss of life and school property in school fires during school strikes. The aim of this study was to examine the contribution of parenting styles towards students' violence in schools, in Embu county. Survey research design was adopted for the study. The study was anchored on Bioecological theory and parenting styles theory. Questionnaires were used to collect data from students on parenting styles and students' violence, focus group discussion schedule was used to collect in-depth views of students while interview schedule were used to collect views of guidance and counseling teachers. Purposive sampling was used to select a sample of 15 schools which had reported more cases of violent behavior out of the 132 secondary schools in the county. Stratified random sampling and systematic random sampling were used to select 399 participants. Purposive sampling was used to select 15 Guidance and counseling teachers from the 15 schools. For the purpose of this study parenting styles were limited to authoritative, authoritarian, and permissive indulgence and permissive neglectful while students' violence was limited to physical fight amongst students and destruction of property in the school. The study found that parents have a big role to play in influencing their children's violent behavior through poor role modeling, inadequate advice and lack of listening to their concerns. The paper discusses contribution of parenting styles on violence among secondary school students in view of these findings.

Contribution/Originality: This study documents the primary role played by home environment through parenting styles and home microsytstem, represented by parent-child relationships in explaining violence among secondary school students in Embu County. The study makes suggestions on ways of addressing the adolescent violence at the family level.

\section{INTRODUCTION}

World over student violence has been a common place feature (Leach, 2003). Rutebuka (2001) contend that, violence is an injustice that is meted on someone or something that is entitled to respect or observance. According to Aluede (2011) violence among students in Canada stands between $10 \%$ and $11 \%$ most of who report having been victimized by peers. According to Onukwufor (2013) in Nigeria, 20.8\% of the secondary school students are physically aggressive, while the prevalence of verbal aggression among the students is 48.3\%. A report by 
Department of Basic Education (2014) over $18 \%$ of the 14 million students in South Africa who attended school in the country in year 2012 experienced physical violence. School violence in its various forms creates an environment of insecurity among students to who the violence s directed and at times the violence is directed to teachers. In most of this violence is rarely reported thus it goes unnoticed by the school authority.

Student violence, both in and out of school, is a common phenomenon in Kenya (Omondi, 2016). In recent times, Kenya has experienced violence school violence in form of school fires, for example, in 2016 alone more than 100 schools were burnt. Students' violence against each other is a common phenomenon in Embu County (Nyaga, 2015). According to Oriya (2005) physical violence in form of fighting among students is frequently reported in secondary schools. Some of the fights resulted in injuries of students. At times Students also direct some of the violence towards school property as they go on strike including arson directed to the school infrastructure. For instance, Mathiu (2008) notes that over the past decade, many secondary schools had suffered from strikes most of which were violent and put the students safety at risk. In recent times, Kenya has experienced violence in form of school fires, for example, in 2016 alone more than 100 schools were burnt. Violence among students in the county is on the rise which is marked by increased school strikes and destruction of school property (Wanzala and Muinde, 2016). Parents are the first social agents of children associate with, and through their parenting roles (expressed through parenting styles) they play an important role in influencing the type of decisions children make on various social issues (Sovet and Metz, 2014). These decisions determine how the children relate with their peers and teachers in school including whether to engage in violence or not (Ikramulah et al., 2009).

\section{PARENTING STYLES THEORY}

Parenting style typology suggested by Macobby and Martins (2003) indentifies four categories of parenting styles: authoritarian, authoritative, permissive indulgence and permissive neglectful. Each parenting style provides unique microclimate in which the child is socialized (Sigelman and Rider, 2009). Authoritarian parenting style combines high control and low warmth. The parent sets strict rules that must be followed without the parents explaining why the child should follow them. Failure to obey the set rules, the child is subjected to punishment (Kinai, 2002). Authoritarian parenting is also high in monitoring and supervision of the Childs' activities. Authoritative parenting style is described as warm, responsive and demanding (Somaye and Rozumah, 2009). It is characterized by: high monitoring, and moderate control of the child's activities. At the same time parent is responsive to the child (Macobby and Martins, 2003). The authoritative parent gives strict rules as well as explaining why the rules must be followed, while at the same time listening to the concerns of the child

Permissive indulgent parent provides little control to the child while being very responsive. According to Hunt (2013) a permissive indulgent parent is seen by the child as a resource to be used without the child being accountable. The child is also allowed to regulate his/her own behaviour. On the other hand, permissive neglecting parent is uninvolved with childs' activities and do not offer control or warmth to the child. Neglectful parents neither provide rules, nor monitoring or supervision to children nor provide little or no communication. The parents are detached from the needs of their children; they do not seem to care about their children and at times may even reject their own children.

\section{BIOECOLOGICAL THEORY}

Bioecological theory by Bronfenbrenner and Morris (2006) broadly explains the effect of social environment on developmental outcomes of a child. The theory divides the social environment into five sub-systems: the microsystem, mesosystem, macrosystem, exosystem and chronosystem. Each sub-system contributes uniquely to the developmental outcomes and social competencies of the child. The main focus of the study was microsystem subsystem, with special reference to parent-child relationships represented by parenting styles. The theory basically postulates that, child development takes place through a process of complex interactions over a period of time. 
These interactions involve; an active child and the people, objects and symbols in the childs' immediate environment.

Bronfenbrenner and Morris (2006) emphasizes on four underlying components of the model: process, person, context, and time (PPCT). Process is basically the foundation of the model; it refers to the relationship between the child and his/her environment over a period of time. Since the study focused on the microsystem, the family interactions mainly parent adolescent relationships represents the process in the model. There are proximal processes and distal processes, where proximal processes are the transactions between the child and the immediate environment consisting of parents which is responsible for the child's competences and general well being. A proximal process varies depending on the characteristics of the developing person and context in which the child is found. On the other hand, distal processes are family's ability to support the child as he/she interacts with other environment (Bronfenbrenner, 2001). On the other hand context, study is made up of a pattern of events, social role and interpersonal relations experienced by the developing person. These activities occur in a given face to face setting with particular physical, social and symbolic features that invite, permit or inhibit engagement in sustained interactions with the immediate environment such as involvement or avoidance of violence

\section{LITERATURE REVIEW}

According to a report by United Nations Educational, Scientific and Cultural Organization (United Nations Educational Scientific and Cultural Organization, 2017) School violence and bullying occurs throughout the world and affects a significant proportion of children and adolescents. It is estimated that 246 million children and adolescents experience school violence and bullying in some form every year. This has resulted in schools increasingly being viewed not as shelters of good manners, human values and civic conflicts solving strategies for young people, but rather institutions prone to violence and deviant behaviour characterized by deviant norms (Fuchs, 2008). In Canada, between 10\% to $11 \%$ of students report having experienced violence from peers (Aluede, 2011). A study carried out in Uganda by Devries et al. (2014) showed that, the levels of violence against both disabled and non disabled children was extremely high. Egbochuku (2007) examined bullying in government and private/mission schools within Nigeria. The study revealed that, majority of students (78\%) were victims of bullying on at least once while $71 \%$ hand bullied others at least once.

Post independence Kenya has experienced school violence some of which has had disastrous results such cases include the St Kizito tragedy, where male students invaded girls dormitories as a result, 19 girls died and 72 were raped, the Kyanguli secondary school fire in Machakos where several students died due to a fire started by colleague students. According to Institute for Security Studies (Institute for Security Studies, 2008) students' violence directed at school property mainly arson has been on the rise in Kenyan secondary schools. The most recent school violence being that of school fires in 2016 where more than 100 schools were burnt in a span of two months (Mabel, 2016). Other forms of violent behaviours common to students in schools commonly referred to as bullying include physical fight, threats, verbal abuse, and intimidation (Sugut, 2013). Bullying among students may include use of verbal, physical or emotional violence on a person who is not in a position to defend him/herself (Kim et al., 2004). A study by Ndetei et al. (2017) on bullying I secondary schools in Nairobi found that Between 63.2\% (640) and $81.8 \%$ (828) of students reported various types of bullying, both direct and indirect, with significant variations found for sex, age, class and year of study, whether in day or boarding school. Ruto (2009) contends that students who are victims of violence may suffer physical deformities, humiliation, withdrawal, poor academic performance or even death. Studies show that students who are bullies seem to be associated with certain familial parenting factors.

Student's violence against other students, teachers or school property may be linked to home background such as parenting styles, among others (Burows, 2015). Jabeen et al. (2013) investigated role of maternal and paternal parenting styles on the prediction of emotional regulation among adolescents. A sample of 194 adolescents was 
used. Regression analysis revealed that, maternal authoritative parenting style had significant positive effect on emotion regulation. Maternal permissive parenting style had significant negative effect on emotion regulation. Similarly authoritative paternal parenting style had significant positive effect on emotional regulation whereas paternal permissive parenting style had significant negative effect on emotion regulation. Emotional regulation is an indicator of display of aggression and subsequent violence. Studies have also shown that parents' aggressive behaviour may be related to aggression in children. If children are constantly exposed to aggressive behaviour they might use the same behaviours on other children (Laible et al., 2004). For instance a study by Githae $e t$ al. (2015) examined relationship between parenting styles and participation of secondary school boys in violence within Gatanga sub-county in Murang'a. The study adopted correlational research design. The results reveal a highly significant association between paternal physical presence and treatment of youths and participation in youth violence.

Parents play a significant role in influencing their children behavioral outcome. For instance Smith and Moore (2013) investigated relationship between parenting style and adolescents' psychological and behavioural well-being in the Jamaican context. The results indicated that authoritarian parenting was associated with diminished psychological and behavioural adjustment, such that adolescents who reported their parents as more authoritarian also reported a greater risk of anger. Anger is a precursor to violence. Thus such adolescents are more likely to be involved in violent behaviors n schools. Muli (2012) carried out a study on factors influencing secondary school student's unrest in Nairobi, and the study used a sample of 792 respondent made up of 22 head teachers 110 teacher and 660 students. The study found that among the factors that may cause violence and school unrest include parents' lack of concern for their children. In yet another study Hoever et al. (2009) carried out a metaanalysis of 161 published and unpublished manuscripts to determine whether there is an association between parenting and delinquency behaviour such as adolescence violence and the magnitude of the linkage is. The analysis found that, the strongest links were between parental monitoring, psychological control, and negative aspects of support such as rejection and hostility of parents towards their adolescent children, accounting for up to $11 \%$ of the variance in delinquency.

\section{RESEARCH METHODOLOGY}

The study targeted secondary school students in Embu County. Descriptive survey research design was adopted for the study, which enabled the research to collect information on respondents' habits, thoughts and opinions from a representative sample by use of questionnaires, interview schedule and focused group discussion schedules. Stratified random sampling was used to select participating schools, to ensure representation of all the categories of the schools. From each category of school simple random sampling was used to select participating respondents. 1 focus group made of 8 members was selected on voluntary basis from each school, making 15 groups. From each school one guidance and counseling teacher was purposively selected. A sample of 399 ongoing students was determined using a sampling formula recommended by Gakungu et al. (2012).

$$
\mathrm{SS}=\frac{\mathrm{N}}{1+\mathrm{N}\left(\mathrm{e}^{2}\right)}=\frac{8820}{1+8820(0.05)^{2}}=399
$$

Where; ss = required sample size

$\mathrm{N}=$ Target Population $=8820$,

$\mathrm{e}=$ Level of precision (sampling error in this case 0.05)

$\mathrm{n}=$ Study sample 399 
Data was collected by use of a four-point likert scale questionnaires, focus group discussion schedule and interview schedule. Data from guidance and counseling teachers were collected by use of interview schedule. Focus group discussion schedule was used to conduct the group discussions. Analysis of data was done thematically and represented inform of frequency tables.

\section{STUDY FINDINGS}

\subsection{Descriptive Statistics on Parenting Styles}

The parenting styles covered by this study includes the following; authoritative, authoritarian, permissive indulgent and permissive neglectful. On parenting styles, Items 1-15 were on authoritative parenting styles, items 16-30 were on authoritarian parenting style, items 31-45 were on permissive indulgent parenting and items 46-60 were on permissive neglectful parenting. The responses for each item was analyzed and summarized on Table 1.0 Below.

Table-1. Responses on Parenting Styles

\begin{tabular}{|c|c|c|c|c|c|c|c|c|c|c|c|c|}
\hline Parenting style & $\begin{array}{l}\text { SA } \\
\text { Fr }\end{array}$ & $\%$ & $\begin{array}{l}\text { A } \\
\text { Fr }\end{array}$ & $\%$ & $\begin{array}{l}\text { AS } \\
\text { Fr }\end{array}$ & $\%$ & $\begin{array}{l}\text { D } \\
\text { Fr }\end{array}$ & $\%$ & $\begin{array}{l}\text { SD } \\
\text { Fr }\end{array}$ & $\%$ & $\begin{array}{l}\text { Tot } \\
\text { Fr }\end{array}$ & $\%$ \\
\hline Authoritative & 146 & 37 & 113 & 28.4 & 17 & 4.2 & 57 & 14.2 & 65 & 16.2 & 399 & 100.0 \\
\hline Authoritarian & 110 & 27.4 & 88 & 22.1 & 20 & 5.2 & 89 & 22.2 & 92 & 23.1 & 399 & 100 \\
\hline $\begin{array}{l}\text { Permissive } \\
\text { indulgence }\end{array}$ & 92 & 23.0 & 76.7 & 19.2 & 31 & 7.8 & 101 & 25.3 & 99 & 24.7 & 399 & 100 \\
\hline $\begin{array}{l}\text { Permissive } \\
\text { neglectful }\end{array}$ & 74 & 18.5 & 74 & 18.6 & 27 & 6.7 & 112 & 28.0 & 113 & 28.2 & 399 & 100 \\
\hline
\end{tabular}

Table 1.0 shows that, on average majority (37\%) of respondents strongly agreed (SA) with all the statements measuring respondents' view of their parents as authoritative while another $28.4 \% 9 \mathrm{~A}$ ) agreed with the statements. This makes a total of $65.4 \%$ of those who agreed with the statements. These findings reveal that majority of the respondents on average view their parents as authoritative. On the other hand on average $14.2 \%$ disagreed (D) with all the statements while $16.2 \%$ strongly disagreed (SD) with all the statements. An average total percentage of respondents who disagreed with the statements of authoritative parenting were $30.4 \%$, another $4.2 \%$ agreed slightly. The findings reveal that authoritative parenting style is widespread within the parents in the target population. These findings concur with a study conducted by Efobi and Chinyelu (2014) which found authoritative parenting to be more common than other styles among parents of African descent. This could be linked to increased democratization in the society. The findings also show that the degree of authoritativeness varies since responses varied from strongly "agree" to "agree slightly". This means adolescent students are exposed to a varying degree of authoritativeness. Thus the developmental outcomes even within authoritative parenting are likely to vary.

The results on table 1.0 show that, on average, majority $(27.4 \%)$ of respondents strongly agreed (SA) with all the statements measuring respondents' view of their parents as authoritarian, while another $22.0 \%$ agreed (A) with all the statements. This makes a total of $49.4 \%$ who agreed with the all statements. These findings reveal that a large number of respondents on average view their parents as authoritarian. According to Querido et al. (2002) a large number of families of African origin place more emphasis on authoritarianism in their parenting practices than parents in the western societies. On the other hand, on average $22.2 \%$ disagreed (D) with all the statements while $23.1 \%$ strongly disagreed (SD) with all the statements. An average total percentage of respondents who disagreed with the statements of authoritarian parenting were $45.3 \%$, another $5.2 \%$ agreed slightly.

On average, majority (25.3\%) of respondents disagreed (D) with all the statements measuring respondents' view of their parents as permissive indulgent while another $24.7 \%$ strongly disagreed (SD) with all the statements. This makes a total of $50 \%$ of those who disagreed with all the statements. These findings reveal that a large number of respondents on average do not view their parents as permissive indulgent. On the other hand on average $23 \%$ 
strongly agreed (SA) with all the statements on permissive indulgent while $19.2 \%$ agreed (A) with all the statements. An average total percentage of respondents who agreed with the statements of permissive indulgent parenting were $42.2 \%$, and another $7.8 \%$ agreed slightly (AS).

Table1.o. also show that, on average majority $(28.2 \%)$ of respondents strongly disagreed with all the statements measuring respondents' view of their parents as permissive neglectful while another $28.0 \%$ disagreed with all the statements. This makes a total of $46.2 \%$ of those who disagreed with the all statements on permissive neglectful. These findings reveal that a large number of respondents on average do not view their parents as permissive neglectful. On the other hand on average $18.6 \%$ of respondents agreed with all the statements on permissive neglectful while $18.5 \%$ strongly agreed with all the statements on permissive neglectful. An average total percentage of respondents who agreed with the statements of permissive indulgent parenting were $42.2 \%$, and another $6.7 \%$, agreed slightly, making up a total of $48.9 \%$ of respondents who experience neglectful tendencies from their parents. The findings also reveal that permissive neglectful parenting varies in the degree of neglectfulness, since responses varied from "strongly agree" to "agree slightly".

\section{RESPONSE ON STUDENTS VIOLENCE}

Violent behaviour was assessed using 10 items measured on a 5-point likert scale. The minimum score was 10 and the maximum score was 50 , the average score was $10+50=60 / 2=30$. The defining score was 30 . A score of 10- 30 was considered to be low in violence while 31-60 was considered high in violence. Responses were summarized on table 2.obelow.

Table-2. Results on violence among students

\begin{tabular}{l|l|l|l|l|l}
\hline \multicolumn{2}{c|}{ Low } & High & \multicolumn{2}{c}{ Total } \\
\hline Frequency & $\%$ & Frequency & $\%$ & Frequency & $\%$ \\
\hline 128 & 32.1 & 271 & 67.9 & 399 & 100 \\
\hline (Source: Authors)
\end{tabular}

Table 2.0 shows that majority (67\%) of respondents scored highly on the violence scale. This shows that majority of students use various forms of violence against their social and physical environment. The findings also concur with a report by DBE (2014) which found out that over $18 \%$ of 14 million students in South Africa who attended school in the country in year 2012 experienced or used physical violence. The findings confirm the extent of challenges faced by the young people transiting the adolescent stage of development. This requires effective intervention strategies to address the challenge.

\section{RESPONSE FROM FOCUS GROUPS}

\subsection{Ease of Sharing Challenges Related To School Violence with Parents}

The study found that when respondents were asked whether they were comfortable to discuss school violence with their parents, majority $(77 \%)$ found it easy to discuss to discuss violence related issues with parents, while $23 \%$ found it difficult to face their parents. The respondents felt discussing violence was easier as long as the child was not involved in such behaviors in school. These discussions were limited by perception of parents that the children are seeking information in order to experiment with the vices. However some respondents felt that some of the parents are too busy to spare time for discussions. This supports a study by Nundwe (2012) which found that parental occupation, economic activities in which parents were engaged were blamed for keeping the parents too busy to take time to talk with their children, this is the barrier to communication as parents have little time to be with their children. 


\subsection{Students' Preference for Sharing Challenges of Violence in School}

When asked who they preferred to sharing challenges of school violence with between parents, relatives like uncles or aunties, peers or counselors, majority (54\%) said they would prefer their parents, since they felt parents would maintain confidentiality. Relatives were not preferred, reason being that they were vied as people who could talk ill of the students family. 13\% percent preferred their peer while $35 \%$ preferred school counselors. The respondents felt that violence is considered general subject as long as they are not the culprit. The young people are more comfortable with parents on matters which are considered general information such as violence in school and drugs and termination of school programs. However inadequate family time for parent child interactions pushes the adolescents to seek such discussions from other people like the peers who are likely to provide unreliable information. Respondents felt that parents were unavailable for them. The study postulates that, driven by search for autonomy and facilitated by the busy schedule of parents who do not have enough time with their children, secondary school students find themselves spending more time with peers and other strangers from who they get information concerning their challenges.

\subsection{Students' Expectations of their Parents}

Responses from the focus group discussion students' expectation of their parents on how to deal with students' violence in school, were analyzed under three broad themes; understanding and respect, advice giving and being listened to, honesty and role modeling. The study revealed that majority (60\%) expect their parents to understand and respect their feelings. This findings concur with Rosenthal (2011) contend that adolescents feel they deserve respect from their parents. They said that they felt that their expectations were rarely met. The study also reveal that $27 \%$ expect their parents to be honest and good role models, since some parents were alcoholics making them to be violent at home and even within the community. The students agreed that their expectations of their parents were more often not met. As a result, the students engaged in disrespectful behaviours such as bullying and easily lie to their parents and teachers on their innocence. According to Cumsille et al. (2010) if parents are not honest they play a major role in influencing their adolescents' lying since they dispute the sincerity and the moral authority of their parent. The study also shows that $13 \%$ expect parents to give them advice and also listen to their views and feeling; they felt many parents were not available for them. The findings concur with Tyzack (2015) who contend that parents who are there physically and emotionally available for their children' expectations, influence their children to have positive behaviours. The findings also concur with Amour et al. (2007) found that work stress can affect family life at home. The study also show that the respondents look upon their parents as role models of social norms including honesty. The findings concur with the study by Wiese and Freud (2011) found that adolescents are influenced by their parents as role models although they may reflect and modify these models according to their beliefs and social relations.

\subsection{Number of Violence Cases Handled by Guidance and Counseling Teachers}

Response from guidance and counseling teachers on cases of violence they handle in their departments shows that, majority (73\%) of schools recording up to 10 cases per school term (of three months) and some (20\%) recording up to 30 cases. The findings show that many schools are grappling with issues that interfere with the smooth delivery of the school academic programs. The findings concurs those of Robinson (2006) who argue that, globally, adolescence is one of the most challenging stage of a persons' life, due to the complexity and magnitude of biosocial changes that occur during this stage

\section{DISCUSSION}

The major responsibility of every parent is to bring up their child as responsible adults who would fit and contribute positively to the well being of the society. In the effort to achieve this goal parents adopt various 
parenting styles. However different parenting styles have varying behavioral outcome some of which are risky to the child and the society at large among such behavior is violence directed towards other the peers in school and school property. The aim of the study was to explore the influence parenting style on the violent behavior among secondary school students. Parents as the first socializing agents for the children provide a unique psychological climate in which the child learns to respond to different social environments around him or her. The parent-child relationship provided by each parenting styles provide the microsystem each of which provides a unique process and context of the developing child to acquire unique characteristic behavior in each child. The finding of the study shows that, the four parenting styles studied are common in the studied population albeit at varying levels. Authoritative parenting style appear to be more popular while permissive neglectful the least popular. The study also shows that each parenting style varies in degree with respondents varying from strongly agreeing to agree slightly. These variations within the same parenting style means which the microsystem in each family varies thus children develops violent behavior at varying degree. The study also shows that there is high preference of violence among students. The children have their preferences and expectations of their parents in relation to violence. The study reveals that majority of children prefer to share with their parents concerning school violence, expect parents to listen to them and give advice they also expect their parents to understand and respect their feelings as well as being a good role models. Children look upon their children for meaningful dialogue in order to clarify challenging issues faced in school setting such as strikes and bullying. Authoritative parenting style provides microclimate which facilitates a parent child relationship where the parent provides standards to guide the child on behavioral conduct. The parent also explains the reasons behind the requirement and gives the child a chance to express their feelings about the rules. The authoritative parent seems to meet child expectations of their parents. Thus the more authoritative the parent, the higher the chance for the parent has to help the child to develop into a balanced child, who is able to socialize with other people in a nonviolence manner. Allowing the child to express their feelings provides the child with good role modeling of addressing emotional situations, as a result such children are likely to seek dialogue when aggrieved and less likely to bully others. However many parents failed in having enough time with their children in order to address the concerns of their children. Inadequate family time was partly blamed on busy work schedules this left some children exposed to negative peer influence, thus engaging in various forms of violence. Children from authoritarian parents are exposed to a microsystem in which the parent-child relationship is characterized by the parent bullying the child. An authoritarian parent is very strict to the child and does not allow the child to express their concerns. Failure by the child to follow the laid down regulations results to punishment without being given a fair hearing. The relationships end up creating fear in children and frustrations. The expectation of the child to be listened to by parents and accorded understanding is seriously undermined. Instead the child learns from their parent to use violence in solving conflicts. Children also develop resentment for their parents and other authority figures such as school prefects and teachers. Authoritarian parents do not entertain dialogue with the children. Such children are not socialized to listen to others view point instead aggression is their way of expressing themselves. Since children look upon their parents for mentorship, authoritarian parents are models of violence to their children who later transfer the violence to school by bullying fighting and at its worst school strikes and destruction of school property. Permissive indulgent parents are granted excessive freedom and material support to their children. Parents do not demand responsibility from their children's actions, yet children look upon their parents for advice. Lack of set standard provides a microsystem which hinders development emotional regulation. Children from permissive indulgent parents are less likely to model violent behavior from their parents; however they are unlikely to learn emotional regulation and delayed gratification. Since children view their indulgent parents as resource to be used without accountability they are likely to translate this behavior to other members of the society including school community, as such they are more likely to be involved in behaviors such as verbal bullying when their demands are not met by their teachers and peers. On the other hand children from permissive neglectful are left unattended materially and emotionally. These 
students are usually bitter and are easily provoked they are likely to engage in violence in self defense of the bitterness, given that their parent are not bothered with what happens to them.

\section{CONCLUSIONS}

The purpose of the study was to examine the role played by the parenting style in influencing violence among secondary school students in Embu County Kenya. From the findings it can be concluded that, parents have a crucial role of helping their children develop responsible behavior by providing an enabling environment. Parents can do this by practicing parenting styles that enable parents and their children to interact in a manner that will meet children's emotional and material needs and at the same provide guidelines necessary to develop emotional regulation skills. The study also concludes that while some parenting styles are protective of children from violence, some predispose the children. Violence meted on children in the name of discipline and excessive freedom given to children is the hallmark of violence among students.

\section{RECOMMENDATIONS}

The study established that parenting styles plays and an important role in violent behavior among secondary school students. The study also established that all the four parenting styles are common within the study population. The study therefore, recommends that the government through the ministry of education in corroboration with community based organizations develop policies aimed at enhancing more responsibility from students. The study also recommends that the school board of management in corroboration with parents' teachers association organize regular seminars on parenting for the parents to enable them to practice good parenting. The study further recommends that the guidance and counseling in schools should be strengthened in order to engage parents whose children are involved in violence. Further the study recommends that schools in conjunction with religious organizations to mount regular mentorship programs for both parents and students separately aimed at helping parents and their children to address their challenges. The schools administration should initiate clubs in school such as students against violence to help create awareness of dangers of violence in and out of schools.

Funding: This study received no specific financial support.

Competing Interests: The authors declare that they have no competing interests.

Contributors/Acknowledgement: All authors contributed equally to the conception and design of the study.

\section{REFERENCES}

Aluede, O., 2011. Managing bullying problems in Nigerian secondary schools. Some counseling intervention for implementation. African Symposium: Online Journal of the African Educational Research Network, 11(1): 138-144. View at Google Scholar

Amour, N., J. Laverdure, A. Devault and S. Manseau, 2007. The difficulty of balancing work and family life: Impact on the physical and mental health of Quebec families. Gouvernement du Québec (2007). Retrieved from http://www.ncchpp.ca/docs/633-DiffBalancingWorkFamilyLife.pdf [Accessed June 21, 2017].

Bronfenbrenner, U., 2001. The bioecological theory of human development. In N. J. Smelser \& P. B. Baltes (Eds). International Encyclopedia of the Social Andbehavioural Sciences, (10): 6963-6970.

Bronfenbrenner, U. and P.A. Morris, 2006. The bioecological model of human development. In R. M. Lerner. (Ed.), Theoretical models of human development of handbook of child psychology. 6th Edn., Hoboken, NJ: Wiley, 1.

Burows, O., 2015. Parents blamed for rising violence in schools. Retrieved from https://www.capitalfm.co.ke/news/2015/08/parents-blamed-for-rising-violence-in-schools/ [Accessed 11th July 2016]. 
Cumsille, P., N. Darling and M.L. Martínez, 2010. Shading the truth: The patterning of adolescents' decisions to avoid issues, disclose, or lie to parents. Journal of Adolescence, 33(2): 285-296. View at Google Scholar | View at Publisher

Department of Basic Education, 2014. Republic of South Africa 2014. General household survey of South Africa. Retrieved from https://www.education.gov.za [Accessed 7th august, 2016].

Devries, K.M., N. Kyegombe, M. Zuurmond, J. Parkes, J.C. Child, E.J. Walakiria and D. Nake, 2014. Violence against primary school children with disabilities in Uganda: A cross-sectional study. Retrieved from https://www.bmcpublichealth.biomedcentral.com/track/pdf/10.1186/1471-2458-141017 ? site=bmcpublichealth.biomedcentral.com [Accessed 4th july 2017].

Efobi, A. and N.C. Chinyelu, 2014. Relationship between parenting styles and tendency to bullying behaviour among. Journal of Education \& Human Development, 3(1): 507-521. View at Google Scholar

Egbochuku, 2007. Bullying in Nigerian schools: Prevalence study and implications for counseling. Journal of Social Science, 14(1): 65-71. View at Google Scholar | View at Publisher

Fuchs, M., 2008. Impact of school context on violence at schools a multi-level analysis. International Journal of Violence and School, 7: 20-42. View at Google Scholar

Gakungu, N.K., A.N. Gitau, P.N.K. Njoroge and M.W. Kimani, 2012. Solid waste management in Kenya. A case study of public technical training institutions. ICASTOR: Journal of Public Engineering, 5(3): 127-138. View at Google Scholar

Githae, J., M. Fridah and S.K. Vundi, 2015. An examination of the relationship between the parenting style and male youth participation in violence in Gatanga sub-county, Murang'a county in Kenya. International Journal of Education and Research, 3(4): 369-380.

Hoever, M., J.S. Dubas, V.I. Eichelsheim, P.H. Van der Laan, W. Smeenk and J.R. Gerris, 2009. The relationship between parenting and delinquency. Journal of Abnormal Child Psychology, 37(6): 749-775. View at Google Scholar

Hunt, C., 2013. Associations between different parenting styles and child behaviour. Student Dissertations. Theses and Papers.

Ikramulah, E., J. Manlove, C. Carol and A. Moorek, 2009. Parents matters. The role of parents in teens' decision making about sex. Trends in Child Research Brief. Publication \#2009-45.

Institute for Security Studies, 2008. Violence in Kenyan schools spreading. Retrieved from https://issafrica.org/isstoday/violence-in-kenyan-schools-spreading [Accessed 13th October 2016].

Jabeen, F., M. Anis-ul-Haque and M.N. Riaz, 2013. Parenting styles as predictors of emotion regulation among adolescents. Pakistan Journal of Psychological Research, 28(1): 85-105. View at Google Scholar

Kim, Y.S., Y.J. Koh and B.L. Leventhal, 2004. Prevalence of school bullying in Korean middle school students. Archives of Pediatrics \& Adolescent Medicine, 158(8): 737-741. View at Google Scholar | View at Publisher

Kinai, T.K., 2002. Relationship between parental behaviour towards adolescents and their manifest aggression in Nairobi secondary school. Unpublished PhD Thesis: Kenyatta University.

Laible, D., G. Carlo, J. Torquati and L. Ontai, 2004. Children's perceptions of family relationships as assessed in a doll story completion task: Links to parenting, social competence, and externalizing behaviour. Journal of Social Development, 13(4): 551-569. View at Google Scholar | View at Publisher

Leach, F., 2003. Learning to be violent: The role of the school in developing adolescent gendered behaviour. Compare: A Journal of Comparative and International Education, 33(3): 385-400. View at Google Scholar | View at Publisher

Mabel, W., 2016. Over 100 schools burned in Kenya in two months: Tuko. Retrieved from https://tuko.co.ke/160631-kikuyuladies-set-taught-cook-fish.h [Accessed October, 8th, 2016].

Macobby, E.E. and J.A. Martins, 2003. Socialization in context of family: Parent-child interaction. Handbook of child psychology: Socialization, personality, and social development. 4th Edn., New York: Wiley, 4.

Mathiu, M., 2008. No party is innocent in schools fire tragedy. Daily Nation. Retrieved from http//:www.mcser.org/journal/index $\cdot$ php/jesr /article/viewFile/4072/3983 [Accessed 19th, April, 2015].

Muli, F., 2012. Institutional factors influencing students' unrest in secondary schools in Nairobi North district, Kenya (Doctoral Dissertation, University of Nairobi, Kenya). 
Ndetei, D., F.A. Ongecha-Owuor, L. Khashakhala and D. Kokonya, 2017. Bullying in public secondary schools in Nairobi, Kenya. Journal of Child and Adolescent Mental Health, 19(1): 45-55.

Nundwe, C.S., 2012. Barriers to communication between parents and adolescents concerning sexual and reproductive health issues: A case study of Kinondoni municipality, Tanzania. Unpublished Master Dissertation of Muhimbili University.

Nyaga, N.M., 2015. Contribution of selected microsystems to antisocial behaviours among adolescents in secondary schools in Manyatta Sub-County, Embu county, Kenya. Unpublished PhD Thesis. Kenyatta University. Nairobi.

Omondi, C.A., 2016. A Research Project Report Submitted in Partial Fulfillment of the Requirements for Award of Degree of Master of Arts in Peace Education Degree of University of Nairobi.

Onukwufor, J.N., 2013. Physical and verbal aggression among adolescent secondary school students in rivers state of Nigeria. British Journal of Education, 1(2): 62-73. View at Google Scholar

Oriya, R.M., 2005. Factors contributing to students deviant behaviour in secondary schools in Kisumu District. Unpublished Master's Thesis, Kenyatta University, Nairobi, Kenya.

Querido, J.G., T.D. Warner and S.M. Eyberg, 2002. Parenting styles and child behaviour in African American families of preschool children. Retrieved from https://www.researchgate.net/publication/11317916_ [Accessed 9th, April, 2016].

Robinson, E., 2006. Young people and their parents: Supporting families through changes that occur in adolescence. AFRC Briefing No. 1-July 2006. [Accessed February 2016].

Rosenthal, E., 2011. What teenagers really want from their parents. Retrieved from https://patch.com/massachusetts/sharon/what-teenagers-really-want-from-their-parents [Accessed 28, June, 2017].

Rutebuka, K.A., 2001. School violence and unspoken messages to children: The remedy is in your hands. Bash Books: Michigan.

Ruto, J.S., 2009. Sexual abuse of school age children: Evidence from Kenya. Journal of International Cooperation in Education, 12(1): 177-192. View at Google Scholar

Sigelman, C.K. and E.A. Rider, 2009. Life-span human development. 6th Edn., Wadsworth CA: Belmont.

Smith, D.E. and T.M. Moore, 2013. Parenting style and psychosocial outcomes in a sample of Jamaican adolescents. International Journal of Adolescence and Youth, 18(3): 176-190. View at Google Scholar $\mid$ View at Publisher

Somaye, K. and B. Rozumah, 2009. Parenting style and collectivist culture of Malysia: European Journal of Social Sciences, 10(1): 66-73.

Sovet, L. and A.J. Metz, 2014. Parenting styles and career decision-making among French and Korean adolescents. Journal of Vocational Behavior, 84(3): 345-355.

Sugut, 2013. Dealing with different forms of violence among students in secondary school in Nandi South District, Kenya. Journal of Advanced Research, 1(4): 450-462.

Tyzack, A., 2015. Why teenagers need quality time with their parents more than toddlers do. Retrieved from http://www.telegraph.co.uk/newss/health/children/11848710/Why-teenagers-need-quality-time-with-their-parentsmore-than-toddlers-do.html.

United Nations Educational Scientific and Cultural Organization, 2017. School violence and bullying global status report. [Accessed 1January 2018].

Wanzala, O. and J. Muinde, 2016. List of 126 schools hit by unrest. Retrieved from http:// www.List\%20of\%20126\%20schools\%20hit\%20by\%20unrest\%20-_\%20Daily\%20Nation.html.

Wiese, B.S. and A.M. Freud, 2011. Parents as role models: Parental behaviour affects adolescents' plans for work in volvement. International Journal of Behavioral Development, 35(3): 218-224. View at Google Scholar | View at Publisher answerable for any loss, damage or liability etc. caused in relation to/arising out of the use of the content. 